\begin{tabular}{|c|c|c|c|c|c|c|}
\hline \multirow{4}{*}{ Impact Factor: } & ISRA (India) & $=3.117$ & SIS (USA) & $=0.912$ & ICV (Poland) & $=6.630$ \\
\hline & ISI (Dubai, UAI & $=0.829$ & РИНЦ (Russia) & $=0.156$ & PIF (India) & $=1.940$ \\
\hline & GIF (Australia) & $=0.564$ & ESJI (KZ) & $=8.716$ & IBI (India) & $=4.260$ \\
\hline & JIF & $=1.500$ & SJIF (Morocco) & $=5.667$ & OAJI (USA) & $=0.350$ \\
\hline
\end{tabular}

\section{SOI: $1.1 /$ TAS $\quad$ DOI: $10.15863 /$ TAS International Scientific Journal Theoretical \& Applied Science}

p-ISSN: 2308-4944 (print) e-ISSN: 2409-0085 (online)

Year: 2019 Issue: $06 \quad$ Volume: 74

Published: $17.06 .2019 \quad \underline{\text { http://T-Science.org }}$
QR - Issue

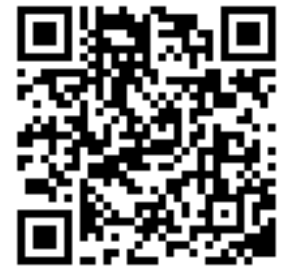

QR - Article

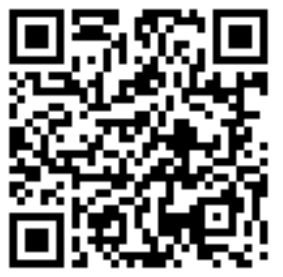

Khurshida Akhmatova

Tashkent University of Information Technology named after Muhammad al-Khorezmi

Lecturer of Department of Economics in IT

\title{
EXPLORING PHYSICAL ACTIVITY AND HEALTH MANAGEMENT SYSTEM ARE IMPROVEMENT OF LIFE QUALITY IN UZBEKISTAN
}

Abstract: In this article basis of economic methods and it's offered to improve the management process of the national system of the mass involvement of all segments of the population, especially children and young people, in sports activities. In the educational system, the mass character can be solved with an integrated approach, effective interaction of all structural bodies of management, as well as through the social club structure. Today, the key issue of mass physical activity remains unresolved - how to attract, how to shape the population's need for regular physical activity. In addition, in world practice, there is practically no effective system for managing the process of mass involvement of all segments of the population in regular sports activities.

Key words: physical activity, health management, economic prosperity, management, competition, reforms.

Language: English

Citation: Akhmatova, K. (2019). Exploring physical activity and health management system are improvement of life quality in Uzbekistan. ISJ Theoretical \& Applied Science, 06 (74), 274-283.

Soi: http://s-o-i.org/1.1/TAS-06-74-33 Doi: crostef https://dx.doi.org/10.15863/TAS.2019.06.74.33

\section{PURPOSE}

Main objectivity of the study is improving the management of the national system of continuous involvement of population into physical activity for raising human capital and engaging mass sports for targeting economic growth in the country through effective management methods.

\section{INTRODUCTION}

Socialization on and through sport is responsible for the role of sport in any society. It is obvious that this role can be developed if the society has the economic resources necessary for investments in sport (for coaching, sport fields, clubs, players etc.) and the willingness to invest in it. High life standards create variety into the family life style, sport practicing at any age being an indicator of the quality of life. Our investment in children`s formal, informal and nonformal education has an obvious importance. We have to stress here not only on the formal-institutional approach but also on the values induced by family, other scholar activities etc. Among the values directly and indirectly cultivated through sport activities we can consider the following ones: fair-play, the capacity to organize and coordinate activities, knowledge of and following the rules (Baciu, A., 2006).
Milteer \& Gilsburg (2012) underlined the fact that play enhances physical health by building active, healthy bodies. Also, physical activity beginning in early childhood prevents obesity and may be included as an important strategy in addressing the obesity epidemic. Play contributes to healthy brain development, as the authors stated, because through physical activity children engage and interact with the world around them from a very early age. In the academic environment, play foster school engagement, and enhances children's learning readiness, learning behaviors, and problem-solving skills. Also is essential to developing social and emotional ties. In a study conducted in Australia, aiming swimming clubs for teens, the coaches and parents both agreed that sports contribute to quality of life by developing personal discipline, setting goals, and striving to reach them and sacrifice for delayed benefits (Light, 2010:389) [1].

As Coakley (2011) underlined, it is widely spread the idea that sport contribute to young people development due to the fact that induces a general well-being state and other positive outputs for those who are practicing sport. Sport promoters consider that sport inevitably leads to multiple forms of development including facilitating socialization/socialization, community revitalization 


\begin{tabular}{|c|c|c|c|c|c|c|}
\hline \multirow{4}{*}{ Impact Factor: } & ISRA (India) & $=3.117$ & SIS (USA) & $=0.912$ & ICV (Poland) & $=6.630$ \\
\hline & ISI (Dubai, UAI & $=0.829$ & РИНЦ (Russia & $=0.156$ & PIF (India) & $=1.940$ \\
\hline & GIF (Australia) & $=0.564$ & ESJI (KZ) & $=8.716$ & IBI (India) & $=4.260$ \\
\hline & JIF & $=1.500$ & SJIF (Morocco & $=5.667$ & OAJI (USA) & $=0.350$ \\
\hline
\end{tabular}

through human bonding enhancement and commitment in relationship with others. (Giulianotti, 2004). Coming from this perspective sport is seen, according to Giulianotti (2004), as a problem-solving activity meant to improve the quality of life for individuals and communities. As we already stated, there are many benefits of sport practicing but, in what concerns adolescents and young people, sport promoters consider three major categories of positive outputs as following: personal development, positive influence upon at-risk populations (for instance juvenile delinquents, children at risk of social exclusion) and fostering social capital that leads to successful civic engagement (Coalter, 2007) [2].

Coakley (2011:308) highlighted the following outputs that sport participation can deliver: creates motor-specific skills convertible into physical capital, improves general physical health, enhance self-esteem and self-confidence inducing a positive body image, forms well shaped characters by encouraging discipline and team work. If we take into consideration that socialization can be defined as a complex process through which individuals, in their interactions with others, accumulate skills, knowledge, values, norms, attitudes and desirable behaviors for their existence into the society frame, we can understand the socialization role of sport. Activities structured around generally accepted values, alternative activities conducted by adults in controlled environments, teaching them self-control, authority recognition, conformation to rules, positive adult role models, are some of the expected outcomes of sport, for at-risk populations of teens (Coakley, 2011:308). [3]

\section{METHODS}

In this article it is used ground theoretical approach and secondary source data analysis of various international sources.

\section{RESULTS}

In developed countries, modern conveniences and technology have contributed to increasing physical inactivity among adults. For example, World Health Organization (WHO) reported in 2008, 31\% of adults exhibit a sedentary lifestyle, and have a $20-30 \%$ increased risk of mortality compared to active people. Therefore, increasing the level of physical activity to help them become more active, and hence reduce the burden of chronic diseases and improve health- related quality of life (HRQL) is considered important [4].

The key to healthy physical activity is awareness of its result in the present and honestly following it with deep respect and constant feedback. Before you rush into battle and act, you must learn to act, for which it is important to first know your purpose and learn to be at ease.

Before embarking on bodily movement training, a person needs to curb his main muscular organ, the tongue. Only after attaining peace in consciousness and language can a person acquire peace and true movement in the body. Lack of physical activity is the fourth largest risk factor for death in the world. Insufficient physical activity is one of the main risk factors for development non-communicable diseases such as cardiovascular diseases, cancer and diabetes. Physical activity is important health benefits and contributes prevention of no communicable diseases. Every third adult in the world is not active enough.

Physical activity is any body movement made by skeletal muscle which requires energy consumption, including activity during operation, games, homework, travel and recreational occupations. Intensity of various forms of physical activity varies between people. In order to physical activity brought benefits to the heart and respiratory system it is necessary that each session lasts at least 10 minutes. Regular physical activity of moderate intensity, such as walking, cycling or playing sports, has significant health benefits:

- improved muscle condition as well heart and respiratory system;

- improving bone health and functional health;

- reducing the risk of developing hypertension, ischemic heart disease, stroke, diabetes, breast cancer glands and colon as well as depression;

- reduced risk of falls and fractures neck thigh and spine; and

- basis of energy metabolism and maintain normal weight.

\section{DISCUSSION}

Physical activity (PA) is an essential biological stimulus for the development and maintenance of healthy structures and functions of the human body. Longstanding lack of sufficient PA leads to weaknesses and degeneration of structures and aberrations in metabolism that lead to and appear as functional deficiencies and diseases in a variety of organ systems [5].

Physical activity : is defined as body movement produced by muscle action that increases energy expenditure. It is an encompassing term that includes physical "exercise".

Physical exercise: is a more specific term and implies planned, structured, repetitive and purposeful physical activity, often with the goal of improving or maintaining one's physical fitness. For example, gardening or walking up stairs in one's home may not be classed as structured "exercise", but it is certainly physical activity.

Physical fitness: is a physiological state of wellbeing that provides the foundation for the tasks of daily living, a degree of protection against chronic disease and a basis for participation in sport. In essence, physical fitness describes a set of attributes relating to how well one performs physical activity. 


\begin{tabular}{|c|c|c|c|c|c|c|}
\hline \multirow{4}{*}{ Impact Factor: } & ISRA (India) & $=3.117$ & SIS (USA) & $=0.912$ & ICV (Poland) & $=6.630$ \\
\hline & ISI (Dubai, UAE & $=0.829$ & РИНЦ (Russia) & $=0.156$ & PIF (India) & $=1.940$ \\
\hline & GIF (Australia) & $=0.564$ & ESJI (KZ) & $=8.716$ & IBI (India) & $=4.260$ \\
\hline & JIF & $=1.500$ & SJIF (Morocco) & $=5.667$ & OAJI (USA) & $=0.350$ \\
\hline
\end{tabular}

Health: is a reflection of one's overall physical, mental and social well-being. It is much more than simply an absence of disease. Health, as we all know, is a characteristic that is not stable in time and can vary along a continuum from near death (ill health) to optimal physiologic functioning (high level wellness) (see Figure 1).

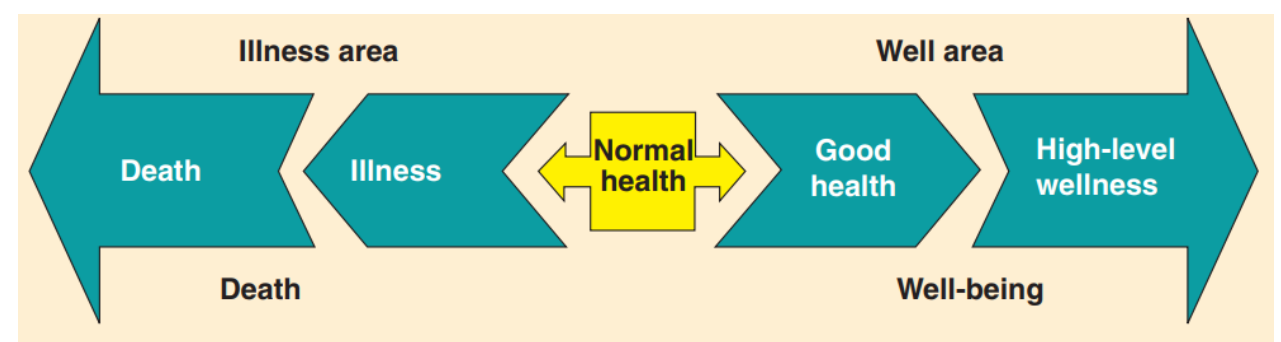

Figure 1. The health and wellness continuum [6]

Source: Dr. Begoña Merino Merino, Elena González Briones, Salud Pública, Physical activity and health in children and adolescents, A guide for all adults involved in educating young people Important concepts of Physical Activity and Physical Fitness, $p 11$.

Causes of insufficient physical activity Decreased levels of physical activity are partly due with passivity during leisure and sedentary lifestyle at work and at home. Increasing use "Passive" modes of transport also contributes to prevalence of inadequate physical activity. A number of environmental factors that associated with urbanization may prevent levels of physical activity of people.

How to increase levels of physical activity?

To increase levels of physical activity you need take action both at the level of society as a whole and at individual level.
Policies aimed at increasing levels of physical activity include:

- Ensuring that all people have access to forms active movement, including walking and driving cycling and ensuring their safety;

- Policy workplace policies promoting physical activity;

- Creating safe sites and premises in schools;

- Formation of high-quality physical education to support the development of behavior patterns in children;

- Creation of sports and recreational facilities

Table 1. Classification of physical activity intensity using \% heart rate reserve and rating of perceived exertion [7].

\begin{tabular}{|c|c|c|}
\hline \multirow{2}{*}{ Intensity descriptor } & \multicolumn{2}{|c|}{ RELATIVE INTENSITY } \\
\cline { 2 - 3 } & $\begin{array}{c}\text { \% Heart rate reserve } \\
\text { (\%HRR) }\end{array}$ & $\begin{array}{c}\text { Rating of perceived } \\
\text { exertion (RPE) }\end{array}$ \\
\hline Very light & $<20$ & $<10$ \\
\hline Light & $20-39$ & $10-11$ \\
\hline Moderate & $40-59$ & $12-13$ \\
Vigorous & $60-84$ & $14-16$ \\
Very vigorous & $>85$ & $17-19$ \\
\hline
\end{tabular}

Source: American College of Sports Medicine Position Stand.The recommended quantity and quality of exercise for developing and maintaining cardiorespiratory and muscular fitness, and flexibility in healthy adults. Med Sci Sports Exerc 1998, 30(6):975-991.

As for the division of the sport activity in this concern we can see above table 1 that, intensity description of activity available among people. It means relative intensity by percentage and ranking of the perceived exertion during physical activity. 


\begin{tabular}{|c|c|c|c|c|c|c|}
\hline \multirow{4}{*}{ Impact Factor: } & ISRA (India) & $=3.117$ & SIS (USA) & $=0.912$ & ICV (Poland) & $=6.630$ \\
\hline & ISI (Dubai, UAE & $=0.829$ & РИНЦ (Russia) & $=0.156$ & PIF (India) & $=1.940$ \\
\hline & GIF (Australia) & $=0.564$ & ESJI (KZ) & $=8.716$ & IBI (India) & $=4.260$ \\
\hline & JIF & $=1.500$ & SJIF (Morocco) & $=5.667$ & OAJI (USA) & $=0.350$ \\
\hline
\end{tabular}

Table 2. Comparison of physical activity recommendations in different countries [8]

\begin{tabular}{|c|c|c|c|c|}
\hline$\overline{\text { Countries }}$ & $\begin{array}{l}\text { Children 6-17 years of } \\
\text { age }\end{array}$ & Adults $18-64$ years of age & $\begin{array}{l}\text { Older adults } 65 \text { years of age } \\
\text { or older }\end{array}$ & References \\
\hline$\overline{\mathrm{USA}}$ & $\begin{array}{l}60 \text { or more minutes of } \\
\text { physical activity each } \\
\text { day }\end{array}$ & $\begin{array}{l}\text { At least } 150 \text { min a week or } 75 \\
\text { min of vigorousactivity each } \\
\text { week }\end{array}$ & $\begin{array}{l}\text { For } 150 \text { min each week or } \\
75 \text { min of vigorous activity } \\
\text { each week }\end{array}$ & $\begin{array}{l}\text { (Department of } \\
\text { Health and } \\
\underline{\text { Human Services }} \\
\underline{2008)}\end{array}$ \\
\hline Canada & $\begin{array}{l}\text { At least } 60 \mathrm{~min} \text { of } \\
\text { moderate- to } \\
\text { vigorous- intensity } \\
\text { physical activity daily }\end{array}$ & $\begin{array}{l}\text { At least } 150 \text { min of moderate- } \\
\text { to } \\
\text { vigorous-intensity physical } \\
\text { activity per week, in bouts of } \\
10 \text { min or more }\end{array}$ & $\begin{array}{l}\text { At least } 150 \text { min of } \\
\text { moderate- to } \\
\text { vigorous-intensity physical } \\
\text { activity per week, in bouts } \\
\text { of } 10 \mathrm{~min} \text { or more }\end{array}$ & $\begin{array}{l}\text { Tremblay, } \\
\underline{\text { Warburton et al. }} \\
\underline{2011)}\end{array}$ \\
\hline UK & For 60 minutes each day & $\begin{array}{l}\text { At least } 30 \text { min of at least } \\
\text { moderate- intensityphysical } \\
\text { activity aday, on } 5 \text { or more } \\
\text { days a week. }\end{array}$ & $\begin{array}{l}\text { In addition to adults, } \\
\text { strength and balance } \\
\text { activities two days per week }\end{array}$ & $\begin{array}{l}\text { (Fiona Bull, Stuart } \\
\text { Biddle et al. 2010) }\end{array}$ \\
\hline Australia & $\begin{array}{l}\text { At least } 60 \mathrm{~min} \text { of } \\
\text { moderate to vigorous } \\
\text { intensity physical activity } \\
\text { every day }\end{array}$ & $\begin{array}{l}\text { Accumulate } 150 \text { to } 300 \mathrm{~min} \text { of } \\
\text { moderate intensity physical } \\
\text { activity or } 75 \text { to } 150 \mathrm{~min} \text { of } \\
\text { vigorous intensity physical } \\
\text { activity each week }\end{array}$ & $\begin{array}{l}\text { At least } 30 \text { min of } \\
\text { moderate intensity physical } \\
\text { activity on most, preferably } \\
\text { all, days. }\end{array}$ & $\begin{array}{l}\text { (Australian } \\
\text { Government } \\
\underline{2014)}\end{array}$ \\
\hline NZ & $\begin{array}{l}60 \text { min or more of } \\
\text { moderate to vigorous } \\
\text { physical activity }\end{array}$ & $\begin{array}{l}30 \text { min of moderate intensity } \\
\text { physical activity on most if not } \\
\text { all days of the week }\end{array}$ & $\begin{array}{l}30 \text { min of moderate } \\
\text { intensity; or for } 15 \text { minutes } \\
\text { vigorous intensity }\end{array}$ & $\begin{array}{l}\text { (Ministry of } \\
\text { Health 2001) }\end{array}$ \\
\hline
\end{tabular}

Source: USA: The United States of America, UK: United Kingdom of Great Britain and Northern Ireland, and NZ: New Zealand

If we compare physical activity recommendations among major countries it would come above statement. In this concern US, UK and Canada which G7 countries which human and social capital are main goal of living style with sport events. It is indicated in ages and time period of recommended issues.

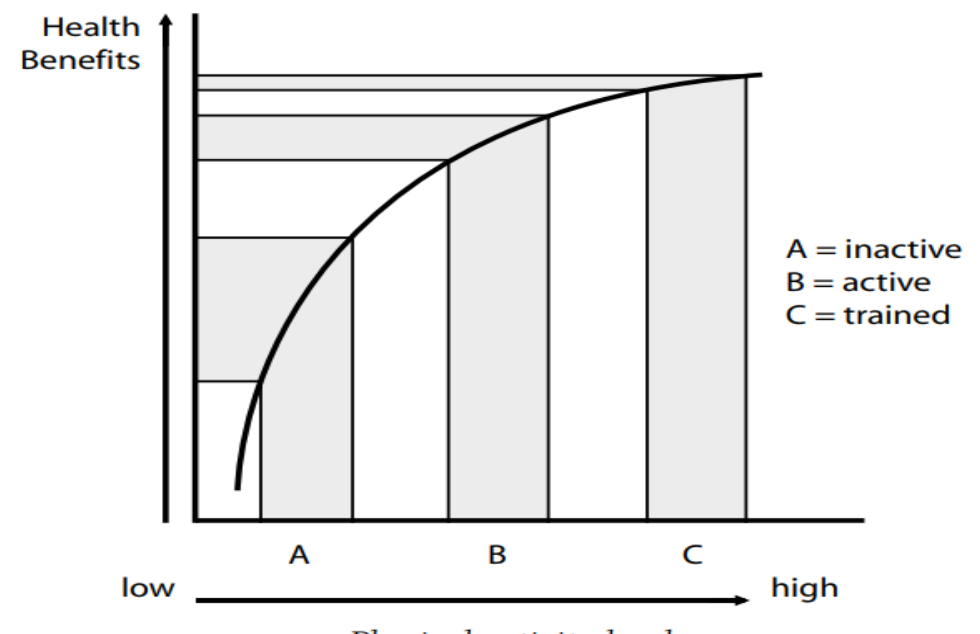

Physical activity level

Figure 2. Dose-response for Physical Activity and health [9]

Source: Steps To Health A European Framework To Promote Physical Activity For Health, WHO Regional Office for Europe Scherfigsvej 8, DK-2100 Copenhagen, Denmark, $p 9$. 


\begin{tabular}{|c|c|c|c|c|c|c|}
\hline \multirow{4}{*}{ Impact Factor: } & ISRA (India) & $=3.117$ & SIS (USA) & $=0.912$ & ICV (Poland) & $=6.630$ \\
\hline & ISI (Dubai, UAE & $=0.829$ & РИНЦ (Russia & $=0.156$ & PIF (India) & $=1.940$ \\
\hline & GIF (Australia) & $=0.564$ & ESJI (KZ) & $=8.716$ & IBI (India) & $=4.260$ \\
\hline & JIF & $=1.500$ & SJIF (Morocce & $=5.667$ & OAJI (USA) & $=0.350$ \\
\hline
\end{tabular}

As shown in the figure 2 dose-response curve above, most health benefits from a given increase in physical activity are achieved through moderate increases in physical activity for inactive persons (section A). Promotional efforts should focus on regular moderate-intensity lifestyle activities. Additional health benefits are achieved by practising more and profitably diverse activity.

Unfortunately, the old approaches, as well as the lack of scientifically based management methodologies, had a negative impact on the system's target tasks associated with the mass involvement of students in sports activity. As a result, the expected social results later turned into routine statistical measures.

In the country, in order to rectify the situation in the field of mass sports, the task is to improve the management and organization of work on mass coverage of all segments of the population with sports activity. In our opinion, such a statement of the problem is of a more fundamental nature and implies economic and administrative and managerial changes in the methods of mass involvement of the population, since the existing management approaches have not become sufficiently effective.

In addition to information about the current prevalence of physical activity behaviors overall and among subgroups, public health monitoring systems also provide information about changes, if any, over time (Figure 3). National estimates of changes in prevalence over time provide information about the overall impact of the multiple factors that influence physical activity behaviors. Data from the National Health Interview Survey suggest that from 1998 through 2015 the prevalence of individuals who report doing no leisure-time moderate-to-vigorous physical activity has declined from about 40 percent to 30 percent.29 The decline has occurred for both women and men.

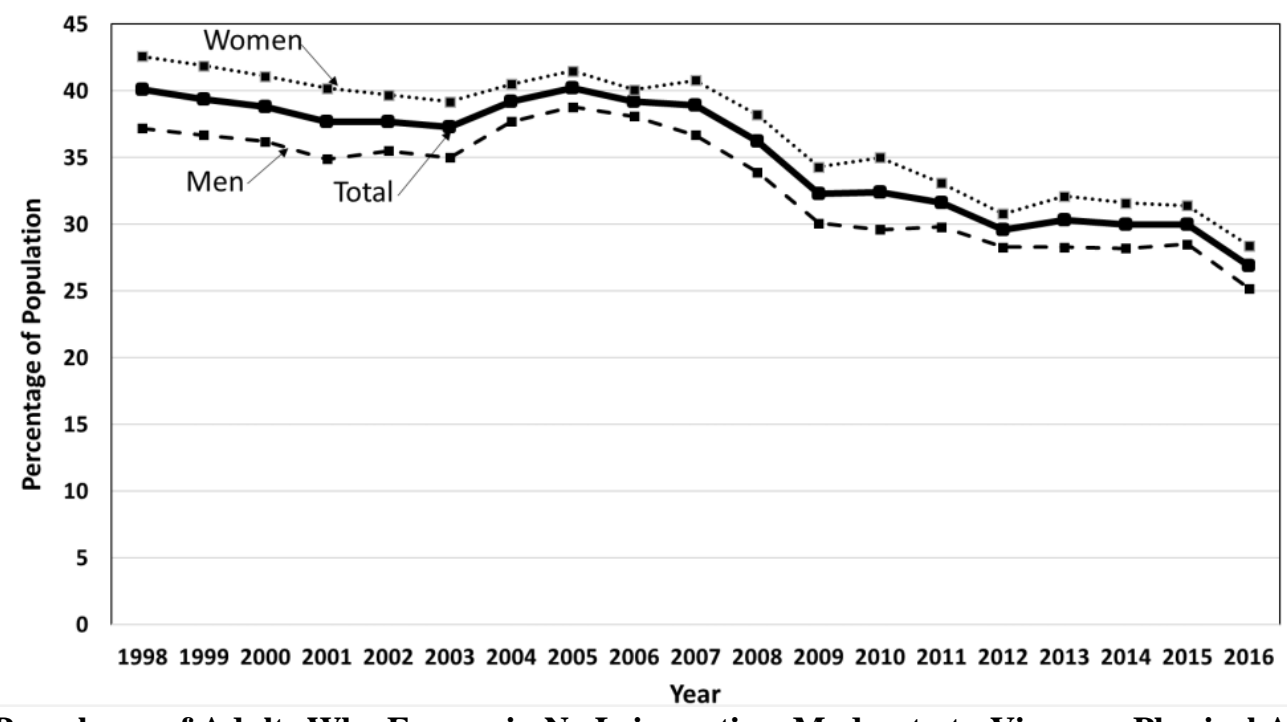

Figure3. Prevalence of Adults Who Engage in No Leisure-time Moderate-to-Vigorous Physical Activity, by Sex and Year, 1998 to 2015 [10]

Source: Otto SJ, Korfage IJ, Polinder S, et al. Association of change in physical activity and body weight with quality of life and mortality in colorectal cancer: a systematic review and meta-analysis. Support Care Cancer. 2015;23(5):1237-1250. doi:10.1007/s00520-014-2480-0.

A commensurate response may be the application of modern methods of socio-economic management decisions in a continuous national system of competitions, which as a way will motivate the interests of the individual, the team and the state to achieve the target results. 


\begin{tabular}{|c|c|c|c|c|c|c|}
\hline \multirow{4}{*}{ Impact Factor: } & ISRA (India) & $=3.117$ & SIS (USA) & $=0.912$ & ICV (Poland) & $=6.630$ \\
\hline & ISI (Dubai, UAE & $=0.829$ & РИНЦ (Russia) & $=0.156$ & PIF (India) & $=1.940$ \\
\hline & GIF (Australia) & $=0.564$ & ESJI (KZ) & $=8.716$ & IBI (India) & $=4.260$ \\
\hline & JIF & $=1.500$ & SJIF (Morocco) & $=5.667$ & OAJI (USA) & $=0.350$ \\
\hline
\end{tabular}

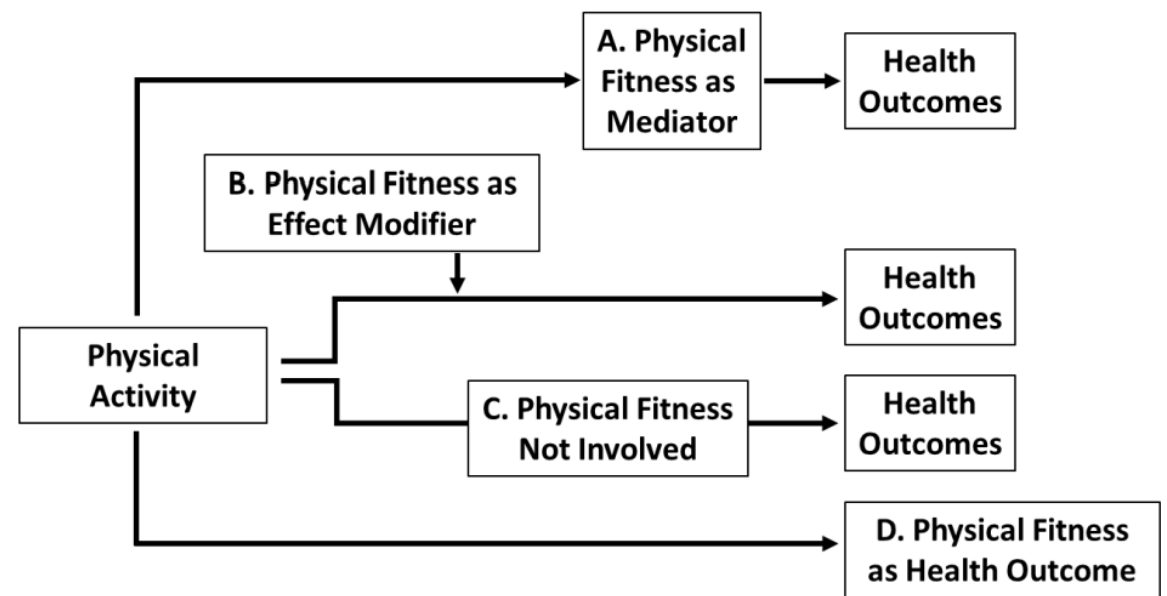

Figure 2. The Role of Physical Fitness along Various Pathways between Physical Activity and Health Outcomes, Observational Studies.

Pathway A: Physical fitness may serve as an intermediate variable along the pathway between physical activity and health outcomes. Synonyms for intermediate variable include contingent variable, intervening (causal) variable, and mediator variable.

Pathway B: Physical fitness may serve as an effect modifier. Synonyms for effect modifier include moderator variable or antecedent moderator.40 Effect modifiers operate outside of the causal chain to influence the effect of the exposure variable on the outcome.
Pathway C: Physical activity may be associated with health outcomes through pathways that do not involve physical fitness.

Pathway D: Physical fitness may be considered as an outcome itself. Individuals who are more physically fit are better able "to carry out daily tasks with vigor and alertness, without undue fatigue, and with ample energy to enjoy leisure time pursuits and to meet unforeseen emergencies"- -in other words, the definition of fitness suggested above [11].
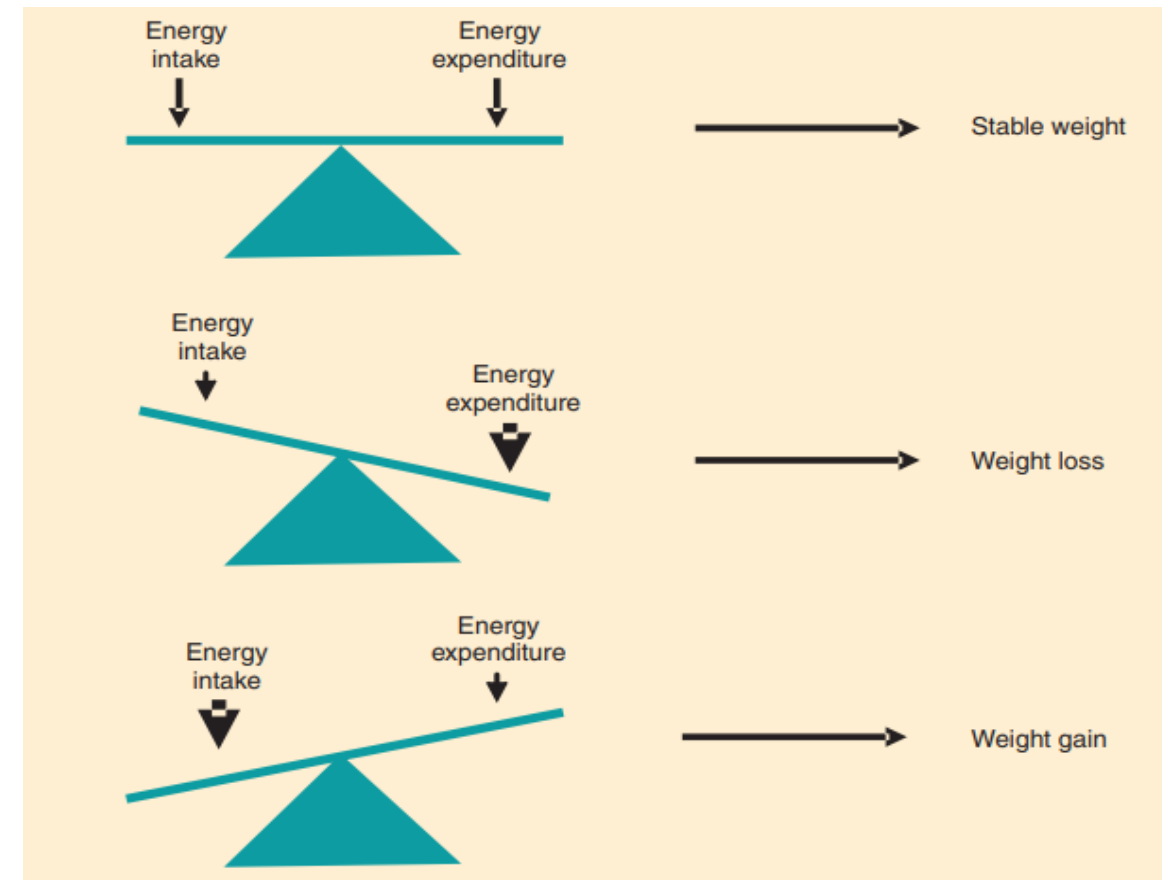

Figure 3. Changes in body weight are determined by a balance of energy intake (food calories) and energy expenditure (calories burned).

Source: Dr. Begoña Merino Merino, Elena González Briones, Salud Pública, Physical activity and health in children and adolescents, A guide for all adults involved in educating young people Important concepts of Physical Activity and Physical Fitness, $p 29$. 


\begin{tabular}{|c|c|c|c|c|c|c|}
\hline \multirow{4}{*}{ Impact Factor: } & ISRA (India) & $=3.117$ & SIS (USA) & $=0.912$ & ICV (Poland) & $=6.630$ \\
\hline & ISI (Dubai, UAE & $=0.829$ & РИНЦ (Russia & $=0.156$ & PIF (India) & $=1.940$ \\
\hline & GIF (Australia) & $=0.564$ & ESJI (KZ) & $=8.716$ & IBI (India) & $=4.260$ \\
\hline & JIF & $=1.500$ & SJIF (Morocce & $=5.667$ & OAJI (USA) & $=0.350$ \\
\hline
\end{tabular}

In the vast majority of cases environmental factors, lifestyle Physical Activity and Health in Children and Adolescents princes and cultural environment are the significant factors that influence obesity. While changes in the diets of children have undoubtedly contributed to increasing global levels of pediatric overweight and obesity, most experts now believe that decreased physical activity is the major contributor.

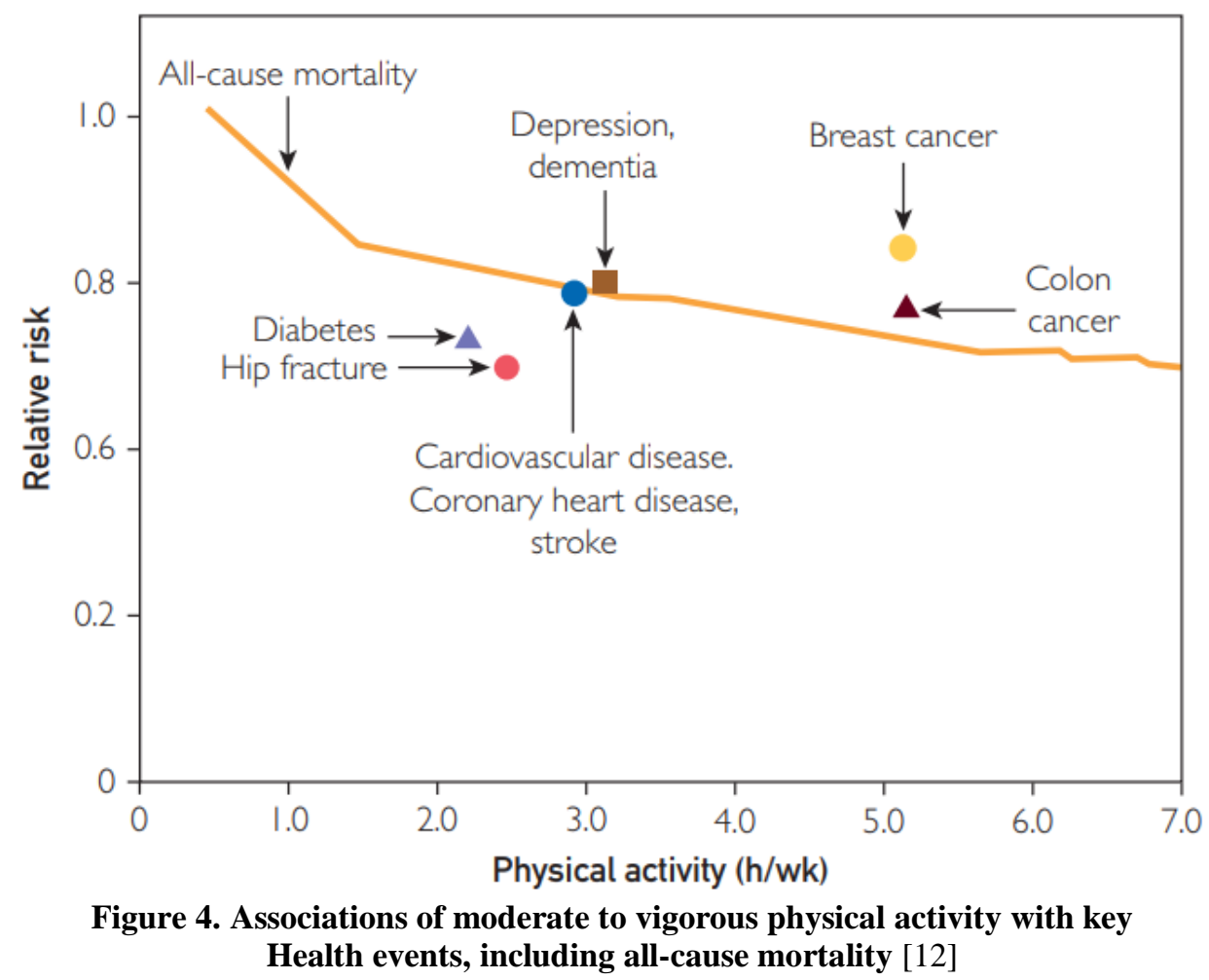

Source: Khan KM, Thompson AM, Blair SN, et al. Sports and exercise as contributors to the health of nations. Lancet. 2012;380(9836):59-64

The regulatory impact of the state on mass sports in the new conditions should be carried out systematically on social as well as economic management bases. Management methods developed on these bases will eliminate the repetition of past mistakes in this field. Today, the management of the mass process should not only consist in the approval of a set of sports events, but in the improvement of managerial methods of influence on the involvement of all segments of the population, especially students in sports activity. Due to this, managed processes will be more flexible and adaptive; there will be a wide possibility of effective control and increasing the level of self-regulation.

The functional orientation and the phased sequence of the national system shows that with proper selection of management tools, as well as with the implementation of the target tasks of each link of the national system, it is possible to organizationally cover all segments of the population, as well as students of the country, with sports activity. At the same time, it is necessary to develop such management forms and methods so that each successive model structure solves specific and clearly formulated tasks in the mass health cycle.

At the beginning of 2000, in accordance with the socio-political tasks and conditions of this period, administrative-management methods and stage-bystage organizational requirements for solving the problem of the mass involvement of millions of students in sports activities were developed in the country.

Analysis of the mechanisms of mass sports management revealed a number of constraints that impede the implementation of the targets of the national model of the sports movement where there was no system of self-organization and self-control, in addition, a template approach was used in organizational management methods in various seasons. 


\begin{tabular}{llllll} 
& ISRA (India) $=\mathbf{3 . 1 1 7}$ & SIS (USA) $=\mathbf{0 . 9 1 2}$ & ICV (Poland) & $\mathbf{= 6 . 6 3 0}$ \\
Impact Factor: & ISI (Dubai, UAE) $=\mathbf{0 . 8 2 9}$ & PUHЦ (Russia) $=\mathbf{0 . 1 5 6}$ & PIF (India) & $=\mathbf{1 . 9 4 0}$ \\
& GIF (Australia) $=\mathbf{0 . 5 6 4}$ & ESJI (KZ) $=\mathbf{8 . 7 1 6}$ & IBI (India) & $\mathbf{4 . 2 6 0}$ \\
& JIF & $\mathbf{1 . 5 0 0}$ & SJIF (Morocco) $=\mathbf{5 . 6 6 7}$ & OAJI (USA) & $\mathbf{= 0 . 3 5 0}$ \\
\hline
\end{tabular}

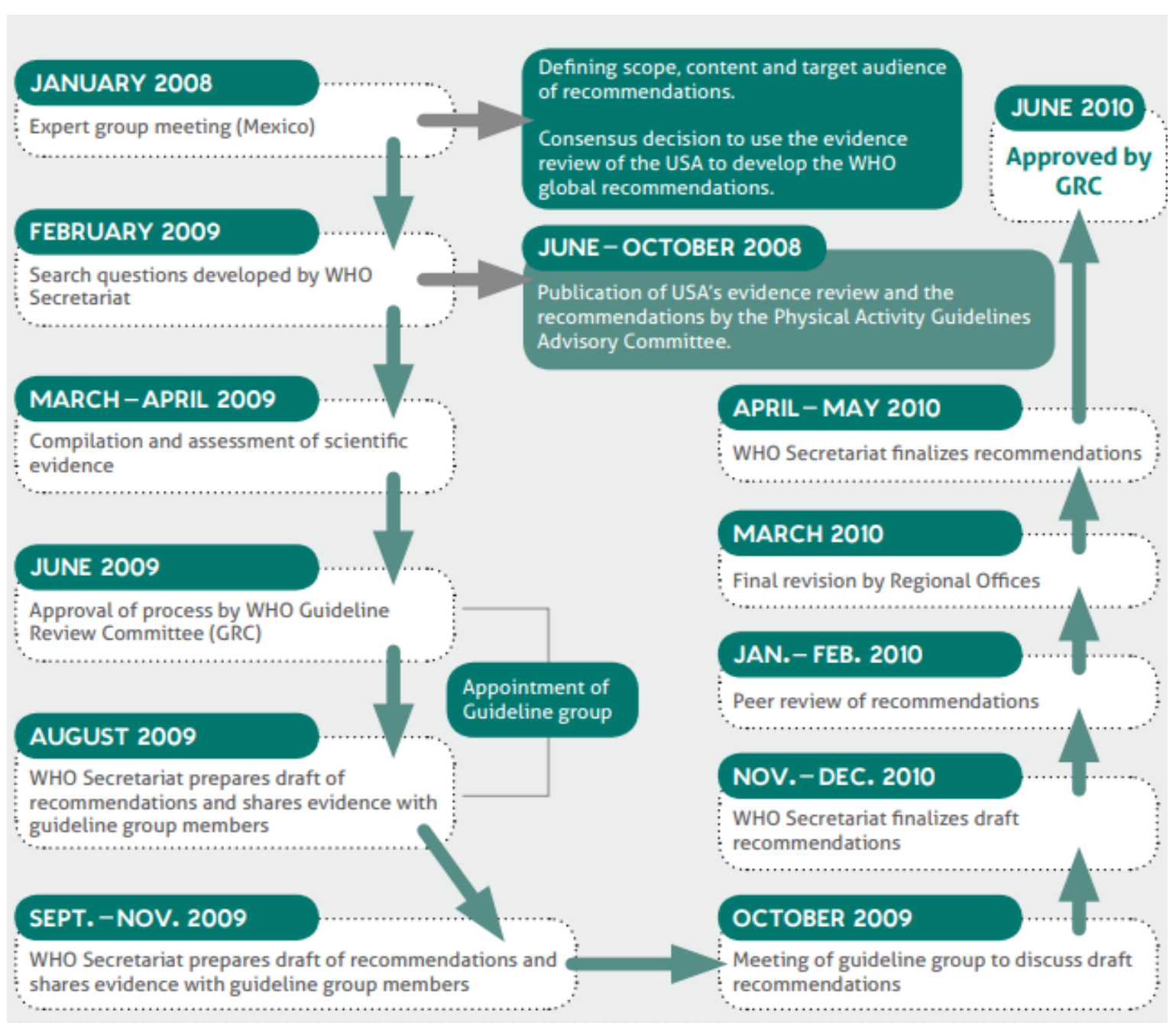

Figure 5. Development of the global recommendations on physical activity for health [13]

Source: Global recommendations on physical activity for health. WHO Library Cataloguing-in-Publication Data, ISBN 9789241599979 (NLM classification: QT 255), p 14.

As a result, the main social task of the national competitive model the system-consistent and continuous involvement of population from all sectors and institutions of the country in mass sports. As a main goal of health resource should be implemented in requested time period as shown figure 5 . It is recommended activities and engaging months for who would like to raise effectiveness in the economy. In macro level it will come to us social capital of the country periodically contributes national economy, society and family with sport management.

Current intentions and reforms in this concern in Uzbekistan

It must be admitted that the management of mass sports movement in educational institutions by means of influencing the motivational sphere is urgently needed, and therefore the use of such mechanisms is increasingly becoming a decisive socio-economic factor of management efficiency.

In management, dissatisfaction with the existing state of affairs is resolved either by improving the existing methods of activity or by developing new ones. In the field of physical education, such a strategy was clearly manifested in the resolution of the President of the Republic of Uzbekistan PP-3031 of 03.06.17 [14]. "On measures for the further development of physical culture and mass sports".

In Uzbekistan, much attention is paid to the development of mass sports as a factor in the reproduction of human capital, therefore, work in this area was associated with the organization and implementation of a competitive system nationwide [8], through which it was planned to continuously involve more than seven million students in physical activity.

Despite the importance of developing students' sustainable need for competitive activity, as well as improving management methods and organizational conditions, the key to raising the level of physical development of students is the interest not only of physical education teachers, but of the entire team of the educational institution. This, in our opinion, is the 


\begin{tabular}{|c|c|c|c|c|c|c|}
\hline \multirow{4}{*}{ Impact Factor: } & ISRA (India) & $=3.117$ & SIS (USA) & $=0.912$ & ICV (Poland) & $=6.630$ \\
\hline & ISI (Dubai, UAI & $=0.829$ & РИНЦ (Russia & $=0.156$ & PIF (India) & $=1.940$ \\
\hline & GIF (Australia) & $=0.564$ & ESJI (KZ) & $=8.716$ & IBI (India) & $=4.260$ \\
\hline & JIF & $=1.500$ & SJIF (Morocco & $=5.667$ & OAJI (USA) & $=0.350$ \\
\hline
\end{tabular}

central aspect of the economic management methods of the social and sports structure of mass involvement of students in sports activities [15].

We believe that the result of physical education can be achieved only with the interest in achieving it, from the teaching staff of the educational institution. In an educational institution, on the basis of an economic method of management, it is necessary to create interest, first of all, using factors not only moral, but also material motivation. Unfortunately, material motivation in the field is practically not used.

The process of formation of interest and involvement in daily sports and physical activities is not a one-time, but a multi-stage and long-term cyclical process. One of the obligatory signs of interest in sports activity of objects of management is the emotional attractiveness to competitions [16].

In the country, a formed system of sports competitions today represents a socially determined orderliness in planning, organizing and holding sports events, with the aim of stimulating the development of mass sports, the growth of sports achievements, and the improvement of people's physical abilities. This system should be improved on the basis of taking into account the interests and financial capabilities of people of different ages and the level of their sports readiness [17].

In view of the above, it is in educational institutions that the need to apply economic management methods arises, since only with the direct and active participation of the entire team of an educational institution, students can be massively involved in motor and competitive activity, and they also form a responsible attitude for their own health.

Therefore, in Uzbekistan, the process of basic formation of skills to a healthy image was built in schools, where there are teachers in physical culture, coaches in sports, a proper sports base, and the possibility of organizing extracurricular activities for the continuous involvement of students in competitive activities.

\section{FINDINGS}

Improving the national competition system based on international cooperation and standards are socio-economic management system for population of the Uzbekistan. It will improve the involvement of generation in educational institutions to physical activity through sport competition, which is a tool for the production and accumulation of the health resource of the population, and health acts. As the main source of future generation of capital qualitatively renewable physical and intellectual resources like "Barkamol Avlod".

\section{CONCLUSION}

We believe that for the implementation of tasks related to the systematic organization of the continuous involvement of students in mass sports based on modern socio-economic management methods, it is advisable in an educational institution to create a structure for managing the school continuous stage of competitive activity. In this case, the proposed structure will be the organization of physical culture and sports activities will act as a sports council or club. Taking into account the interests, abilities and motives for physical education and sports influences government economy and human development index with professional organizational methods. Competitive movement and approach regarding physical activity and health management system pushes economy forward with long life expectancy in Uzbekistan. Healthy generation can generate new idea, innovation and manatee huge projects, transfer technology and prospective economic growth in Uzbekistan.

\section{References:}

1. Milteer, R., M., \& Ginsburg, K, R. (2012). The Importance of Play in Promoting Healthy Child Development and Maintaining Strong ParentChild Bond. American Academy of Pediatrics. Focus on Children in PovertyPediatrics129(1), pp.204-213.

2. Giulianotti, R. (2004). Human rights, globalization and sentimental education: The case of sport. Sport in Society(7), pp.355-369.

3. Coakley, J. (2011). Youth Sports: What Counts as "Positive Development?". Journal of Sport \&
Social Issues, 35(3): pp.306-324. http://jss.sagepub.com/content/35/3/306

4. Mansi, S., \& Mohammed Al Khaldi, H. (2015). Physical Activity Management and its Role for Health Benefits: Narrative Review. International Journal of Health Sciences December 2015, Vol. 3, No. 4, pp. 95-107 ISSN: 2372-5060 (Print), 2372-5079 (Online), DOI: 10.15640/ijhs.v3n4a9 http://dx.doi.org/10.15640/ijhs.v3n4a9

5. Vuori, I. M., Lavie, C. J., \& Blair, S. N. (2013, December). Physical Activity Promotion in the 


\begin{tabular}{|c|c|c|c|c|c|c|}
\hline \multirow{4}{*}{ Impact Factor: } & ISRA (India) & $=3.117$ & SIS (USA) & $=0.912$ & ICV (Poland) & $=6.630$ \\
\hline & ISI (Dubai, UAE & $=0.829$ & РИНЦ (Russia & $=0.156$ & PIF (India) & $=1.940$ \\
\hline & GIF (Australia) & $=0.564$ & ESJI (KZ) & $=8.716$ & IBI (India) & $=4.260$ \\
\hline & JIF & $=1.500$ & SJIF (Morocce & $=5.667$ & OAJI (USA) & $=0.350$ \\
\hline
\end{tabular}

Health Care System, Mayo Clin Proc., 88(12), pp.1446-1461.

www.mayoclinicproceedings.org

6. Merino, B. M., Briones, E. G., \& Pública, S. (n.d.). Physical activity and health in children and adolescents. A guide for all adults involved in educating young people Important concepts of Physical Activity and Physical Fitness, p.11.

7. (1998). American College of Sports Medicine Position Stand. The recommended quantity and quality of exercise for developing and maintaining cardiorespiratory and muscular fitness, and flexibility in healthy adults. Med Sci Sports Exerc 1998, 30(6), pp.975-991.

8. USA: The United States of America, UK: United Kingdom of Great Britain and Northern Ireland, and NZ: New Zealand.

9. (n.d.). Steps To Health A European Framework To Promote Physical Activity For Health, WHO Regional Office for Europe Scherfigsvej 8, DK2100 Copenhagen, Denmark, p.9.

10. Otto, S. J., et al. (2015). Association of change in physical activity and body weight with quality of life and mortality in colorectal cancer: a systematic review and meta-analysis. Support Care Cancer, 23(5), pp.1237-1250. doi:10.1007/s00520-014-2480-0
11. Bird, E. L., Baker, G., Mutrie, N., Ogilvie, D., Sahlqvist, S., \& Powell, J. (2013). Behavior change techniques used to promote walking and cycling: a systematic review. Health Psychol, 32(8), pp.829-838. doi:10.1037/a0032078

12. Khan, K. M., et al. (2012). Sports and exercise as contributors to the health of nations. Lancet, 380(9836), pp.59-64.

13. (n.d.). Global recommendations on physical activity for health. WHO Library Cataloguingin-Publication Data, ISBN 9789241599979 (NLM classification: QT 255), p.14.

14. (2017). Resolution of the President of the Republic of Uzbekistan PP-3031 of 03.06.17. "On measures for the further development of physical culture and mass sports"

15. Riskiev, T., \& Akhmatov, M. (2002). The AllUzbek System of the Continuous Sports Movement. State Patent Organization of the Republic of Uzbekistan, 5 (43), pp.178-179.

16. Doev, V. K. (2011). Formation of a regional system of mass sports management. Scientific problems of humanitarian studies (Economics), №4, p.270.

17. Averkin, N. V., \& Zaichenko, O. M. (2011). Motivational management of the system of physical education and sports education. Public Education, №8, p.204. 